\title{
Feeding 9 billion by 2050 - Putting fish back on the menu
}

\author{
Christophe Béné • Manuel Barange • Rohana Subasinghe • \\ Per Pinstrup-Andersen • Gorka Merino • \\ Gro-Ingunn Hemre • Meryl Williams
}

Received: 11 January 2015 / Accepted: 4 February 2015 / Published online: 10 March 2015

(C) The Author(s) 2015. This article is published with open access at Springerlink.com

\begin{abstract}
Fish provides more than 4.5 billion people with at least $15 \%$ of their average per capita intake of animal protein. Fish's unique nutritional properties make it also essential to the health of billions of consumers in both developed and developing countries. Fish is one of the most efficient converters of feed into high quality food and its carbon footprint is lower compared to other animal production systems. Through fish-related activities (fisheries and aquaculture but also pro-
\end{abstract}

\author{
C. Béné $(\bowtie)$ \\ Institute of Development Studies, University of Sussex, Sussex, UK \\ e-mail: c.bene@cgiar.org \\ M. Barange \\ Plymouth Marine Laboratory, Plymouth, UK \\ e-mail:MABA@pml.ac.uk \\ R. Subasinghe \\ Food and Agriculture Organization, Rome, Italy \\ e-mail: Rohana.Subasinghe@fao.org \\ P. Pinstrup-Andersen \\ Cornell University Ithaca, Ithaca, USA \\ e-mail: pp94@cornell.edu \\ G. Merino \\ AZTI, Pasaia, Gipuzkoa, Spain \\ e-mail: gmerino@azti.es \\ G.-I. Hemre \\ Institute of Nutrition and Seafood Research, Bergen, Norway \\ e-mail: Gro-Ingunn.Hemre@nifes.no \\ M. Williams \\ 17 Agnew Street, Aspely, Queensland, Australia \\ e-mail: meryljwilliams@gmail.com \\ Present Address: \\ C. Béné \\ International Center for Tropical Agriculture, Cali, Colombia
}

cessing and trading), fish contribute substantially to the income and therefore to the indirect food security of more than $10 \%$ of the world population, essentially in developing and emergent countries. Yet, limited attention has been given so far to fish as a key element in food security and nutrition strategies at national level and in wider development discussions and interventions. As a result, the tremendous potential for improving food security and nutrition embodied in the strengthening of the fishery and aquaculture sectors is missed. The purpose of this paper is to make a case for a closer integration of fish into the overall debate and future policy about food security and nutrition. For this, we review the evidence from the contemporary and emerging debates and controversies around fisheries and aquaculture and we discuss them in the light of the issues debated in the wider agriculture/farming literature. The overarching question that underlies this paper is: how and to what extent will fish be able to contribute to feeding 9 billion people in 2050 and beyond?

Keywords Fish · Food security and nutrition · Micro-nutrient deficiency $\cdot$ Fisheries $\cdot$ Aquaculture

\section{Introduction}

Fish is critically important to food security and good nutrition (Allison 2011; Thilsted 2012; Beveridge et al. 2013). Fish and other aquatic foods are high in protein and contain many essential micronutrients. The fishery and aquaculture sectors are the source of income for millions of women and men in lowincome families (Béné 2006), thus contributing directly and indirectly to their food security (Béné et al. 2007; Allison 2011; World Bank/FAO/WorldFish 2012). Yet, the potential contributions of fish to food security and nutrition (FSN) are 
all but ignored in the international debate, as if a firewall stood between the discussions about the role of fish and the broader debates about FSN issues. A recent review of international development and research agencies working on FSN revealed for instance that "fish is strikingly missing from strategies for reduction of micronutrient deficiency, precisely where it could potentially have the largest impact" (Allison et al. 2013: 45).

The purpose of this paper is to make a case for a closer integration of fish into the overall FSN debate. As such the discussion is directed not to those in the fisheries and aquaculture communities who have been relentlessly advocating for fish as an entry point in this debate (see e.g., Béné et al. 2007; Hall et al. 2011; Thilsted 2012), but to the vast majority of the international experts who are influencing the wider debate and policies on FSN.

The World Committee on Food Security (CFS) took an important step in the right direction in 2012 by requesting that the High Level Panel on Food Security (HLPE) undertook an in-depth study of the role of sustainable fisheries and aquaculture for FSN. The report (HLPE 2014) presents the strongest case yet for incorporating fish into the debates on how to achieve FSN for all and suggests a set of activities and policies to be pursued.

Building on this report and a large body of literature, our ambition is to bring fish onto the table. A number of papers have succeeded in presenting a very comprehensive evidencebased argument for supporting fish as a central element in the FSN debate (see e.g., Prein and Ahmed 2000; Roos et al. 2003; 2007; Kawarazuka and Béné 2011; Beveridge et al. 2013). Here, we aim to review the evidence from the contemporary and emerging debates and controversies around fisheries and aquaculture. In doing this we do not go into the microlevel issues concerning social, gendered and micro-economic aspects of fish, FSN at the local levels - for those we refer readers to the HLPE report (HLPE 2014).

Some of the underlying questions in the present study are closely linked to the issues discussed in the wider agriculture/ farming literature. The latest estimate suggests for instance that, in 2009, fish accounted for $17 \%$ of the global population's intake of animal protein and $6.5 \%$ of all protein consumed (FAO 2014). In the context of this Special Issue on "Feeding 9 Billion", the key questions are: a) Can we maintain these consumption rates, given the projected growth in human population and the growing environmental challenges facing the earth? and b) Could fish - one of the most efficient converters of feed into high quality food - be a substitute for other sources of animal protein? Finally, in the context of the current discourse about future resource scarcity, should fish be considered a more environmentally friendly source of protein than the other livestock production systems?

Fish is more than just a source of animal protein. Fish contains several essential amino acids, especially lysine and methionine. The lipid composition of fish, with the presence of long-chain, poly-unsaturated fatty acids (LC-PUFAs), is unique. Fish is also an important source of essential micronutrients - vitamins D, A and B, and minerals (calcium, phosphorus, iodine, zinc, iron and selenium), which makes it particularly attractive in the current fight against malnutrition in low income and food deficient countries (LIFDCs). Some countries (e.g., Zambia, Brazil, or Chile) have already recognized this potential and have included fish in their national school-feeding programmes. Should this be more systematically considered in countries with high levels of malnutrition to complement or substitute the technology-dependant (and expensive) bio-fortification programmes?

In addressing these issues we must first acknowledge that fish production sectors and associated value chains have been remarkably dynamic in the last three decades - what some refer to as the 'blue revolution'. Every second fish we consume is now produced in aquaculture. This new situation is a result of the stagnation of capture fisheries following decades of expansion, some of it carried out in an unsustainable manner (FAO 2012), combined with impressive growth rates in the aquaculture industry, subject to some major adjustments to overcome the early challenges such as fish disease and negative environmental impacts. Critics of aquaculture have also pointed to the use of fishmeal and fish oil produced from wild fish, to feed farmed fish. These concerns are valid and need to be taken (along with their solutions) into account in this discussion.

\section{Understanding fish production in relation to food security and nutrition}

The fastest growing food-supply industry in the world

In 2011, $173 \mathrm{Mt}$ of fish were extracted from the global marine and inland water ecosystems, of which 7 to 10 Mt were discarded prior to landing and $12 \mathrm{Mt}$ were lost at the post-harvest stage. The production from capture fisheries and aquaculture available amounted therefore to $154 \mathrm{Mt}$, of which about $131 \mathrm{Mt}$ were utilized directly for human consumption (Fig. 1) (HLPE 2014). Thanks to aquaculture and fisheries, the global supply of fish has grown by a factor of 8 since 1950. By comparison, even after the Green Revolution the world rice production increased only by a factor of 3 . In effect, fish production has been the fastest growing food industry in the world for the last 40 years and is expected to remain so in the near future. The fish supply per capita has more than tripled in the last half century, from $6 \mathrm{~kg} /$ year in 1950 to $18.8 \mathrm{~kg} /$ year in 2011 - Fig. 2 . In fact, the world fish supply has effectively been growing faster than the world's population (FAO 2012). These global figures mask, however, some important 
Fig. 1 World fish utilization. Notes: a 2011 estimates. b 2010 estimates. Source data from FAO (2012) and Shepherd and Jackson (2013)

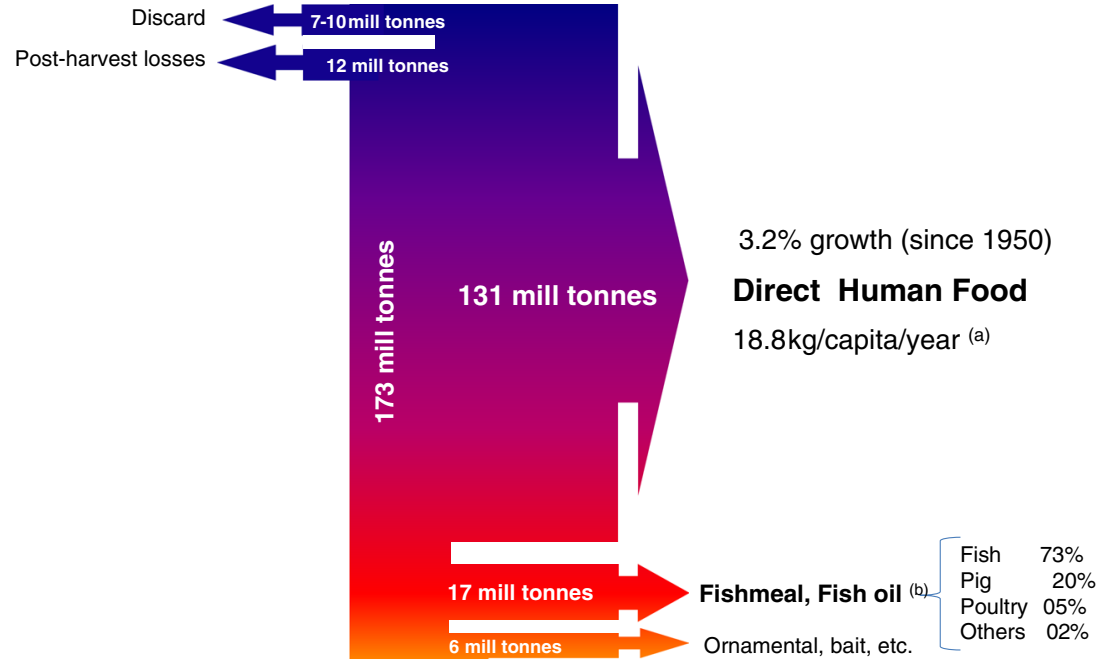

Notes: (a) 2011 estimates. (b) 2010 estimates.

Source data from FAO (2012) and Shepherd and Jackson (2013). regional variations: fish consumption is the lowest in Africa (9.1 kg per capita in 2009), while Asia accounts for almost two-thirds of total consumption $(20.7 \mathrm{~kg}$ per capita).

Fish as the largest source of animal protein

Fish is a major source of animal protein, overshadowing most other sources. In 2010 it represented a source twice as important as poultry, and three times larger than cattle (Fig. 3). Today capture fisheries and aquaculture provide 3 billion people with almost $20 \%$ of their average per capita intake of animal protein, and a further 1.3 billion people with about $15 \%$ of their per capita intake (HLPE 2014). This share can exceed $50 \%$ in some countries. In West Africa, Asian coastal countries, and many small island states, the proportion of total dietary protein from fish can reach $60 \%$ or more (e.g., Gambia, Sierra Leone, Ghana, Cambodia, Bangladesh, Indonesia, Sri Lanka, or the Maldives) (FAO 2014).

The geography of fish as a source of protein is also significant in the FSN discussion. Twenty-two of the 30 countries where fish contribute more than one-third of the total animal protein supply were officially referred to as LIFDCs in 2010 (Kawarazuka and Béné 2011). In other words, almost threequarters of the countries where fish is an important source of animal protein are poor (income-wise) and food-deficient. Yet
Fig. 2 Relative contribution of aquaculture and capture fisheries to production and food fish supply. Source: FAO Statistics and Information Branch of the Fisheries and Aquaculture Department

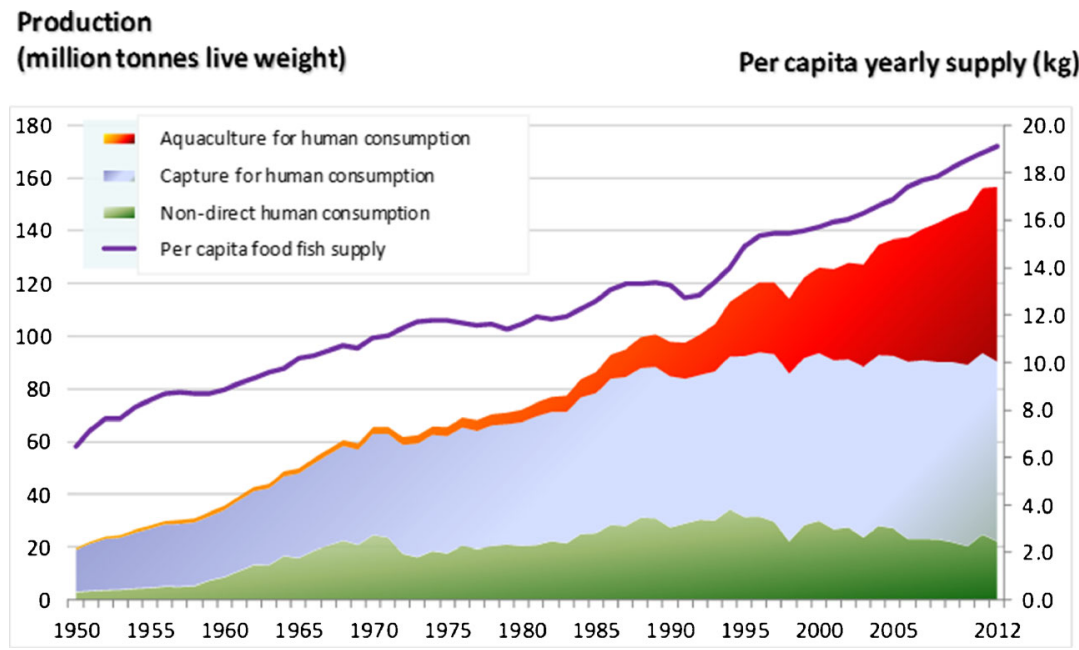

Source: FAO Statistics and Information Branch of the Fisheries and Aquaculture Department. 
Fig. 3 World Production of the main sources of animal protein over the period 1960-2010.

Source: FAO Stat

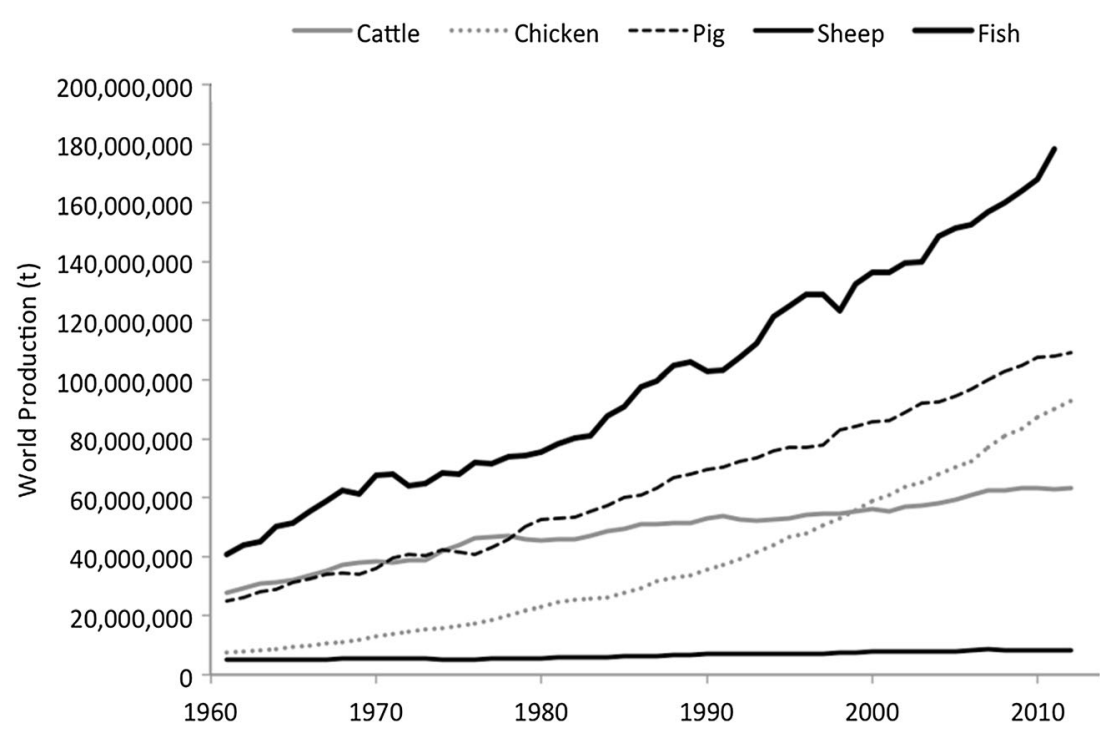

in these LIFDCs, even if fish is a substantial proportion of the food intake, undernourishment can still occur as total food intake is often insufficient.

Fish - beyond protein...

Some point out, however, that the main contribution of fish to FSN may not be in relation to its protein content, but its lipid and micro-nutrient content.

The lipid composition of fish is unique, having LC-PUFAs, with many beneficial effects for child development and adult health (Thilsted et al. 1997; Larsen et al. 2011; Richardson and Montgomery 2005). Among fish species that are cheaper in developing countries, small pelagic fish such as anchovy and sardine are some of the richest in LC-PUFAs (USDA 2011), especially compared to large freshwater fish such as carp and tilapia. When its rich nutrient content is preserved, fish can provide protective effects against a wide range of health issues. LC-PUFAs for instance provide protection against diseases such as stroke, high blood pressure or coronary heart disease (Miles and Calder 2012; Rangel-Huerta et al. 2012).

Complementing its fatty acid content, fish is also known to be an important source of essential micronutrients - vitamins D and B, and minerals (Roos et al. 2003; 2007; Bonham et al. 2009). Lipid-rich fish also contain vitamin A. Recent research showed that fish species consumed whole with bones, heads, and viscera play a critical role in micronutrient intakes of people as these parts are where most micronutrients are concentrated. Some of these small fish (such as mola (Amblypharyngodon mola), darkina (Esomus danricus), sardines and pilchards, anchovy, seabass, tilapia) contain high levels of minerals such as calcium, phosphorus, iodine, zinc, iron and selenium, which are low in other foods. The potential contribution that fish (even in small quantity) can therefore offer to address multiple micronutrient deficiencies is now being recognized (e.g., Roos et al. 2007; Kawarazuka and Béné 2011; Thilsted 2012). For instance, the high level of iodine found in fish can help prevent iodine deficiency which is known to cause cretinism (stunted growth and mental retardation).

\section{Current issues in relation to fish contribution to food security}

Fishmeal and fish oil in aquaculture

In addition to being used directly as human food, fish also contributes indirectly to human nutrition when it is used as fishmeal for aquaculture and poultry/livestock feeds (Tacon and Metian 2009). In 2011, 23 Mt of fish - essentially small pelagic fish species such as anchovy, herring, mackerel and sardine - have been destined to non-direct human consumption, of which $75 \%$ (17 Mt) was reduced to fishmeal and fish oil for aquaculture, poultry and other livestock feeding (cf. Fig. 1). In 2010, $73 \%$ of the total world fishmeal was used to feed farmed fish, followed by pigs $(20 \%)$, poultry $(5 \%)$ and others (2\%) (Shepherd and Jackson 2013).

From a FSN perspective, the use of fishmeal for farmed fish (and livestock) raises important issues. Leaving aside the debate on the role of small pelagic fish in supporting larger fish, birds and marine mammals in the ecosystem (Smith et al. 2010), is fishmeal the most efficient way to use fish (especially low-cost small pelagic fish rich in LC-PUFA) or would these fish contribute more to food security if a larger share of them was eaten directly by people? Indeed, despite some substantial improvement in the last decade, the rate of conversion of fishmeal to fish is still a source of concern (Troell et al. 
2014). On average, for every $\mathrm{kg}$ of farmed fish produced, $0.7 \mathrm{~kg}$ of wild fish is needed (Tacon and Metian 2008). This average figure, however, masks important differences: while for omnivorous farmed fish, the rate is down to an acceptable 0.2 to $1.41 \mathrm{~kg}$ of wild fish per $1.0 \mathrm{~kg}$ of farmed fish, for carnivorous farmed fish, the figure is higher: 1.35 to $5.16 \mathrm{~kg}$ to produce one $\mathrm{kg}$ of farmed fish (Boyd et al. 2007).

Fish losses and implications on food security and nutrition

The global discards of fish (fish caught but dumped overboard due to low quality, damage or spoilage, non-targeted species or below regulation size) were estimated to be around 7.3 Mt in $2005,80 \%$ of which coming from industrial fleets. In contrast, small-scale fisheries generate less wastage in the form of discards (about $2 \mathrm{Mt}$ a year, that is, $4 \%$ of their estimated landing ${ }^{1}$ ) (Kelleher 2005).

With increasing fish scarcity and increasing fish prices, species previously deemed commercially inferior are progressively integrated into consumer eating habits and markets. Most shrimp trawlers, which used to discard up to $95 \%$ of their catch, are now landing more bycatch for human consumption (Béné et al. 2007). In small-scale fisheries where discarding fish is rare, substantial quantities and quality are lost due to post-harvest mishandling during transport, storage, processing, on the way to markets and waiting to be sold. Especially in developing countries, where access to electricity and cold chain can still be an issue, fish post-harvest losses can be significant. Estimated at 10-12 Mt in 2005, the total accounts for $10 \%$ of global capture and culture fisheries' production (Béné et al. 2007). While physical losses in smallscale fisheries are less than $5 \%$, economic losses can be substantial. In Africa, some estimates (FAO Focus nd) put postharvest losses in some cases to levels as high as 20-25\%. In aquaculture, waste streams in value chains have been large in the past but are tending to decline rapidly as competitive pressures force innovation (Arthur et al. 2013).

Sustainability of fisheries and implications for food security

Because total fish production (availability) is an important dimension of food security, a key issue in this debate is the environmental sustainability of capture fisheries. The extent to which capture fisheries have exceeded sustainable levels has generated strong expert and public opinion debates (Worm et al. 2006; Pauly et al. 2005; Hilborn 2013) and many media headlines, scientific papers and environmental campaigns have been in the last two decades framed around the idea that world fisheries resources are in crisis due to overfishing (see e.g., Pauly et al. 1998; Myers and Worm 2003). FAO has

\footnotetext{
${ }^{1}$ Overall, small scale fisheries land approximately $40 \mathrm{Mt}$ annually, compared to $50 \mathrm{Mt}$ by large scale fisheries (HLPE 2014).
}

expressed a more nuanced but nonetheless concerned view about the state of world marine fisheries (e.g., FAO 2012), acknowledging the granularity in the state of resources worldwide. The current consensus is that global fisheries would be more productive if the levels of overfishing were reduced (Srinivasan et al. 2010), and the environmental sustainability of fisheries were recognized to be a sine qua none condition for FSN (HLPE 2014).

An important point in this debate, however, is that improving FSN through fisheries would depend on stock recovery and also on access to and distribution of the harvest, as well as gender consideration (de Schutter 2012; Williams 2010). Indeed overfishing per se is only one aspect of the problem. Other economic activities, such as oil drilling, coastal development, pollution, or dams and water flow management have significant negative impact on aquatic habitats (Halpern et al. 2008).

Indirect contribution to food security and nutrition through livelihood support

A critical pathway to enhance FSN is through the income that people generate from engaging in remunerated activities. In this respect aquaculture and fisheries (especially through the number of small-scale operators engaged in fishing, aquaculture, processing, and trading businesses - see e.g., Béné et al. 2010) play a critical role in low income and emergent countries. Altogether it is estimated that between 660 and 820 million people (fishers, fish-farmers, fish traders, workers in fish processing factories, and their families) depend on fishrelated activities as a source of income (Allison et al. 2013; HLPE 2014). This represents more than $10 \%$ of the world population. For most of these households, the revenues generated may not necessarily be very high (Neiland and Béné 2004; Allison et al. 2011; Béné and Friend 2011), but it is often the main component of their livelihood, which allows them to secure accessibility to food (Heck et al. 2007; Béné et al. 2009; Eide et al. 2011).

\section{Feeding 9 billion by 2050: where does fish stand?}

The global human population is expected to exceed 9 billion by 2050 (UN estimates), increasing the pressure on the food sectors to maximize production and reduce waste. Production increase must occur in a sustainable way and in a context where key resources, such as land and water, are likely to be scarcer and where climatic change impact will intensify. The fish-production sector is no exception.

In this context two key questions emerge. First, will fisheries and aquaculture be able to maintain the current global fish consumption rate of $18 \mathrm{~kg}$ per capita per year, and the equivalent regional values, and if not, how will society 
address the needs of expected winners and losers (Barange et al. 2014)? So far technological and institutional innovations have ensured that the combined production of fish through fisheries and aquaculture has been faster than the world population's demand of fish. The question is now whether we can keep up this pace with another 2 billion people added in the next 35 years, and how the four dimensions of food security (availability, accessibility/affordability, utilization and stability) will be balanced to ensure that fish go to those who need them most (Merino et al. 2012).

The second key question is whether sustainable fisheries and aquaculture will be able to help address the bigger food security issue that will affect the world in the coming decades? In particular, could aquaculture become a substitute form of protein for some of the less efficient food production systems, or even be used to compensate for the decline in farming systems' productivity that is predicted as a consequence of the impact of climate change?

How much fish do we need?

\section{Global drivers of fish demand}

World population is often presented as a key driver for the growth in seafood demand and for fisheries development. In reality, a more important driver for fish (and other animalsource food) consumption is income (Speedy 2003). Demand for fish as food is particularly high in the wealthier strata of societies, including in the low-income countries, and as income will continue to increase in highly populated countries such as China and India, demand levels are likely to rise more strongly (Garcia and Rosenberg 2010). Overall, a large increase in the number of people moving into the middle class, particularly but not exclusively in Asia, is likely to result in a very large expansion in the demand for fish.

Income is, however, not the only driver of fish demand. It is recognized that urbanization is also an important factor increasing animal-source food consumption in general and fish consumption in particular. Delgado et al. (1997) suggest that changes in food preference driven by urbanization alone have, in the past, accounted for an extra 5.7-9.3 kg per capita consumption of meat and fish per year. Similarly, Betru and Kawashima (2009) and Toufique and Belton (2014) present data from Ethiopia and Bangladesh, indicating that urbanization affects animal food consumption rates independently of income.

These different factors explain the rapid increase in demand for meat, milk, and fish in the emerging economies of Asia. In China, for example, the demand for fish is likely to increase from $24.4 \mathrm{~kg}$ per person per year in 2000 to $41 \mathrm{~kg}$ per person per year by 2030 (World Bank 2014).

\section{Demand projection}

Modelling exercises have been conducted recently with the objective of estimating the projections of fish demand and supply. These modelling exercises include the World BankFAO-IFPRI Fish 2030 analysis elaborated on the IMPACT model developed by the International Food Policy Research Institute (IFPRI) (World Bank 2014); the OECD-FAO Agricultural outlook model built on the combined multimarket, partial equilibrium AgLink-CoSiMo model (OECD-FAO 2013; Lem et al. 2014); and a series of peerreviewed articles relying on various types of modelling and projection tools (Rice and Garcia 2011; Merino et al. 2010, 2012; Barange et al. 2014). The time horizon of these different analyses is not always the same. For instance, the OECD-FAO outlook model works over a 10 year-projection period (i.e., up to 2023 as per the last iteration of the model), while the World Bank-FAO-IFPRI model runs until 2030; Merino et al. 2010 used a 20 year simulation, calibrated on a 1997-2004 data set (meaning technically that their projection runs until 2024), while Merino et al. (2012) and Barange et al. (2014) proposed a projection up to 2050. A strict comparison of the different projections is therefore difficult.

A bigger issue is that very few of these studies integrated information on the drivers of changes (the combination of urbanization and increase in income), to estimate with accuracy the future demand for fish across the world. Many studies assume constant consumption rates in the future (e.g., Barange et al. 2014) or fixed nutritional targets (Rice and Garcia 2011). Others worked directly with projected fish consumption (e.g., OECD-FAO 2013; Merino et al. 2012), that is, by dividing the projected supply by the projected population. None of these approaches therefore offers an appropriate basis for estimating the actual demand for fish. The World Bank-FAO-IFPRI study uses regional fish consumption rates to estimate the global demand but the report does not clarify how these figures are constructed. $^{2}$ Aggregating the regional figures at the global level, the report estimates that the world demand for fish will be around $152 \mathrm{Mt}$ in 2030 (World Bank 2014).

Merino et al. (2012) estimated the expected production capacity of marine ecosystems exploited under maximum sustainable yield principles, and projected aquaculture production requirements to achieve a range of food consumption targets. They concluded that between 125 and $210 \mathrm{Mt}$ of fish by 2050 will be necessary to maintain fish consumption at around 15$20 \mathrm{~kg}$ per capita per year. Starting from a different angle, Rice

\footnotetext{
${ }^{2}$ The report explains that "For the subsequent years in the simulation [after 2000 which was used as the base year for the calibration], these intercept values [between supply and demand] are changed according to the exogenous growth rates specified for each of the supply and demand functions" (World Bank 2014: 23, our emphasis). It is not clear from the report how the exogenous growth rates in regional demand have been computed in the model.
} 
and Garcia (2011) sought to estimate the need for additional fish necessary to supply $20 \%$ of the dietary protein requirement to feed a 9 billion population by 2050 . On this basis, an additional production of $75 \mathrm{Mt}$ of fish from fisheries and aquaculture would be needed above the 2006 production level (144 Mt), that is, approximately $215 \mathrm{Mt}$. This represents an almost $50 \%$ increase in production with respect to the 2006 level. While this figure is above other projections, it has the advantage that it starts from an actual estimate of the future needs (as opposed to the estimate of apparent consumption rates), but without factoring in future production potentials or market responses to the fishmeal/fish oil demand (see below).

In summary, the current understanding of the global drivers of fish demand (urbanization and increase in living standards in developing and emerged countries) is relatively well established but not all of the current models have integrated these drivers comprehensively. In comparison, the efforts to better understand the ability of the world to produce fish in the future (i.e., the supply side of the equation) have been more elaborate.

The future of fisheries production and the impact of climate change

A consensus has emerged in the literature that the doom-andgloom rhetoric that had driven the discussion surrounding the state of marine fisheries in the late 2000s (Garcia and Grainger 2005; Caddy and Seijo 2005) was exaggerated (Grafton et al. 2010; Hilborn 2010) and that although the situation remains concerning in respect to many stocks, we are not likely to face the global collapse that had been announced by some biologists (e.g., Myers and Worm 2003; Worm et al. 2006; Pauly 2009). Instead, the downward trend of overfished stocks may have been reined in (Fig. 4). ${ }^{3}$ Reflecting this, most of the projections proposed in the recent literature estimate that the global fisheries' landings are likely to be stable in the short to medium term. The OECD-FAO model for instance estimates that capture fisheries will be $5 \%$ higher by 2024 than it is was in 2013, that is, around $96 \mathrm{Mt}$ (OECD-FAO 2013) while the World Bank-FAO-IFPRI model estimates that this will be around $93 \mathrm{Mt}$ in 2030. These figures are at a global scale however, and some regional outlooks are for good stock rebuilding, while others are for a worsening in overfishing.

Yet another key factor for which much uncertainty remains is the impact of climate change. Unlike most terrestrial animals, aquatic animal species are poikilothermic (coldblooded) and changes in aquatic habitat temperatures will more rapidly and significantly influence distribution, prey availability, metabolism, growth and reproduction, with

\footnotetext{
${ }_{3}$ According to the FAO, the number of stocks fished at unsustainable levels decreased from $32.5 \%$ in 2008 to $28.8 \%$ in 2011 (FAO 2014).
}

stronger impact on fishing and aquaculture distribution and productivity (Cheung et al. 2009). At the same time however, the interconnectedness of aquatic systems allows many species to change spatial distribution more easily as ecosystems shift, to remain in their zones of preference. Clearly, therefore, the impact of global climate change on ocean capture fisheries will be important. Biological predictions based on oceanatmosphere general circulation models (OA-GCMs) have already demonstrated that the physical and chemical properties of the oceans will be modified, affecting the productivity, distribution, seasonality and efficiency of food webs, from primary producers to fish (Steinacher et al. 2010; Cheung et al. 2009, 2011). Some of these earlier GCM models however, were limited by their coarse resolution, too low to capture the processes that dominate the dynamics of the world's coastal and shelf regions, where most fisheries operate. More advanced models are now available (e.g., Merino et al. 2012; Blanchard et al. 2012; Barange et al. 2014).

Overall, and with few exceptions, the conclusion of all these models is that although climate change will alter the present geographical distribution of shelf-sea ecosystems productivity, in most of the regions and EEZs, the overall potential impact is projected to be low to moderate. Barange et al. (2014), for instance, used a high resolution shelf-sea physicalbiological model that allowed them to scale down the analysis and gave greater confidence in predicting the consequences at national scales. They conclude that by 2050 , estimates of national fish production should remain on average within $\pm 10 \%$ of the present yields.

\section{The contribution of aquaculture to future fish supply}

The second element on the supply side is aquaculture. Discussion of the rise of aquaculture has so far largely focused on its contribution to global aquatic animal food supplies, ignoring the resultant changes in species composition of the fishes consumed, how it is farmed, and the implications for food and nutrition security (Kawarazuka and Béné 2011; UNHRC 2012). As a consequence, our understanding mainly concerns the question of the ability of the aquaculture industry to maintain its rate of growth. In this regard, most of the recent analyses agree that the era of exponential growth is over and while the sector will still continue to grow, the projected rate of growth is expected to decelerate. The main causes of this slower growth are likely to be freshwater scarcity, lower availability of locations for optimal production, and high costs of fishmeal, fish oil and other feeds (FAO 2012). Nonetheless, the World Bank-FAO-IFPRI model suggests this rate will still be sufficient to maintain a steady rise, reaching the point where it will equal global fisheries production by 2030 around 93 Mt (World Bank 2014) (Fig. 5). Technical innovation, improved farm and animal health management, and improved and more efficient germplasm will be responsible for 
Fig. 4 Global trends in the state of world marine fish stocks (1974-2011). Source: FAO (2012)

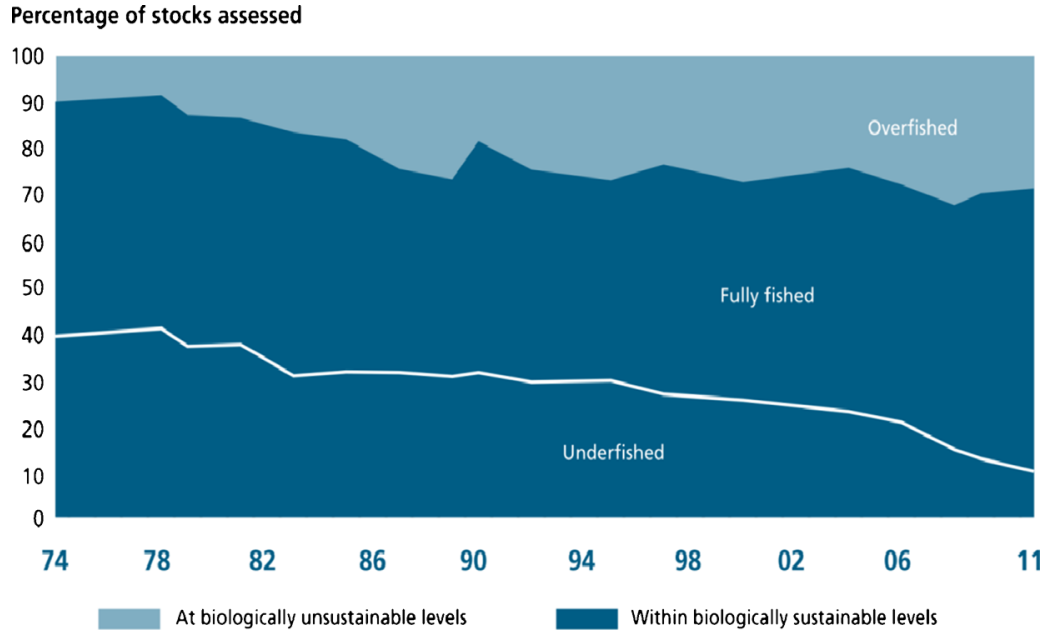

Source: FAO (2012) this increased growth, in combination with the continued expansion of fish-farming. Combined with a projected capture fish production that will remain fairly stable over the 2000 2030 period (see above), the global fish supply is projected to rise to $187 \mathrm{Mt}$ by 2030 (World Bank 2014). These figures are consistent with the projections proposed by OECD-FAO in which the global fish production will reach $181 \mathrm{Mt}$ in 2022, of which $161 \mathrm{Mt}$ would be destined for direct human consumption (OECD-FAO 2013).

A key element in this discussion is the importance of fishmeal and fish oil and how markets and technological innovations will respond to price signals (Merino et al. 2010, 2012; FAO 2012; World Bank 2014; Troell et al. 2014). ${ }^{4}$ The consensus is that the use of fishmeal in aquaculture feeds is expected to decrease in percentage with time, thanks to increasingly effective replacements, including plant proteins, waste products from fish and terrestrial animals and use of better/improved breeds of aquatic animals with better feed conversion (Tacon et al. 2011). Formulated feeds are a significant factor in production costs, and this is a strong incentive to develop technology that will make feeds more affordable and sustainable. Overall, the proportion of fish used for nondirect human consumption has decreased from $30 \%$ in the early 1990s to $15 \%$ in 2010 and the World Bank analysis concluded that the projected expansion of aquaculture will be achieved with only an $8 \%$ increase in the global fishmeal supply during the 2010-2030 period (World Bank 2014).

\footnotetext{
${ }^{4}$ For instance, one of the 6 selected scenarios of the World Bank-FAOIFPRI's analysis is specifically focusing on these issues (Scenario 2 "Expanded Use of Fish Processing Waste in Fishmeal and Fish Oil Production") (World Bank 2014) and one of the selected issues of the 2012 FAO SOFiA report was on "Demand and supply of aquafeed and feed ingredients for farmed fish and crustaceans: trends and future prospects" (FAO 2012: 171-182).
}

Putting all the pieces together

Given the very rough projections for fish demand and the more elaborate projections for fish supply just reviewed above, will fisheries and aquaculture be able to maintain their current contribution to food security in the future? The answer that emerges from the literature is that as far as food availability and demands are concerned, it is a conditional yes. All the projection models currently available seem to agree that the overall fish consumption rate could be maintained, in other words, that the fisheries and aquaculture aggregated growth will keep up with population growth rates. In fact, the OECDFAO even estimates that the world fish consumption will increase by another $10 \%$ and reach $20.9 \mathrm{~kg}$ per capita per year by 2023 . The World Bank-FAO-IFPRI report is slightly more

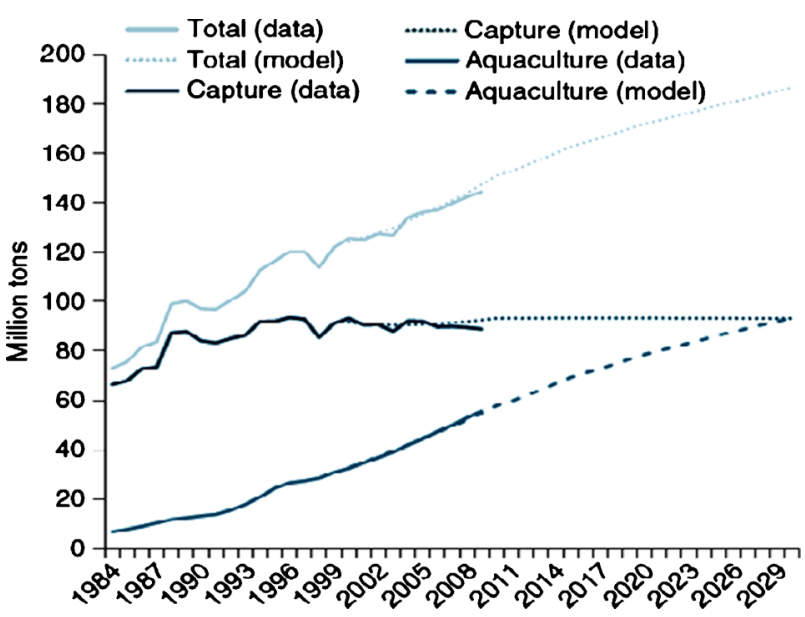

Data source: FAO FishStat and IMPACT projection model.

Fig. 5 Global fish production: data and projection 1984-2030 from the IMPACT model (World Bank 2014). Data source: FAO FishStat and IMPACT projection model 
conservative and estimates that the per capita fish consumption will remain at around $18 \mathrm{~kg}$ per year in 2030 . Merino et al. (2012) and Barange et al. (2014) reached the same conclusion for 2050 , but this is essentially due to the underlying assumptions of their models.

All these analyses, however, stress the fact that for this outcome to occur, several specific conditions must be satisfied: capture fisheries will need to be exploited according to sustainable principles; very significant technological development will need to take place in aquaculture feeds to reduce fishmeal dependency and in farm management and germplasm to improve the overall efficiency of aquaculture; and discards, waste and losses will need to be reduced. Some of these conditions could be particularly challenging and a 'business-as-usual' approach is expected to fail. ${ }^{5}$

In addition to whether or not the world (and the markets) will be responsible enough to ensure that these conditions are satisfied, the question of who will be the winners and losers is vital to the other key FSN issues, which are: access to livelihoods in fish value chains and affordability of fish. Unfortunately, the consensus is that in the coming decades, the current situation regarding the imbalance between consumers in developed and developing countries is unlikely to change. While the present figures indicate the lowest fish consumption per capita in Africa (9.1 kg in 2009), the different models project that this imbalance will deteriorate further. The OECD expects that per capita consumption in Africa will decrease by a further $10 \%$ by 2024 , while that of Asia will show the highest growth rate $(+14 \%$, OECDFAO 2013). The World Bank-FAO-IFPRI projection (World Bank 2014) is even more alarming with per capita fish consumption expected to decline in sub-Saharan Africa by $1 \%$ annually to $5.6 \mathrm{~kg}$ in $2030 .{ }^{6}$ Yet at the same time developing countries will account for more than $91 \%$ of the total increase in fish consumption. Even so, their annual per capita fish consumption will still remain below that of more developed regions (19.8 vs. $24.2 \mathrm{~kg}$ ) (World Bank 2014).

A last important point needs to be mentioned. In view of the importance of income growth and urbanization as drivers of fish demand, the objective of merely maintaining fish production growth rate at the same level as the growth in world population would not be enough to prevent fish price from increasing. The urban population with the highest income

\footnotetext{
${ }^{5}$ Merino et al. (2012) estimate that the fish used in aquaculture feed to produce one unit of output would have to be reduced by at least $50 \%$ from current levels to secure sustainability. If not, demand will push the price of fishmeal products up to levels where the short term economic incentive to exploit small pelagic (the main source of this fishmeal) beyond their maximum sustainable yield would be high, potentially leading to increases in fishing capacity and rapid depletion of resources.

${ }^{6}$ Some other regions of the world are also expected to face lower fish consumption rate per capita: Japan, Latin America, Europe, and Central Asia.
}

growth will increase fish consumption while low-income people will experience reductions in their fish consumption. This is an important distributional and food security consequence. To avoid that, fish production needs to expand faster than population growth.

\section{Can fish contribute further to the 2050 global food security challenge?}

The arguments presented above are mainly constructed around a sectorial perspective. At least three other transsectorial (or systemic) arguments should be considered in relation to the wider debate of 'feeding 9 billion by 2050'.

First, in terms of animal protein availability, with $18.2 \mathrm{~kg}$ per capita per year, fish is providing 115,133 , and $189 \%$ more protein per capita than pig, poultry and beef respectively. In fact, fish (combining capture fisheries and aquaculture) has been the main contributor to the $61 \%$ increase in the world per capita consumption of animal protein for the period 1969 2009 (Table 1). As economic development is expected to continue driving an increasing trend in animal protein demand, (OECD-FAO 2013) and aquaculture is projected to remain the fastest growing food commodity sector, this sector will soon become even more central in the future food security of the world population.

Table 1 World per capita meat and fish food supply (kg per capita per year) 1969-2009

\begin{tabular}{|c|c|c|c|c|c|}
\hline & 1969 & 1979 & 1989 & 1999 & 2009 \\
\hline \multirow[t]{2}{*}{ Pig meat } & 9.4 & 11.5 & 13.1 & 15.1 & 15.8 \\
\hline & $25.2 \%$ & $27.7 \%$ & $28.2 \%$ & $28.1 \%$ & $26.3 \%$ \\
\hline \multirow[t]{2}{*}{ Poultry meat } & 3.8 & 5.6 & 7.3 & 10.7 & 13.6 \\
\hline & $10.2 \%$ & $13.5 \%$ & $15.7 \%$ & $19.9 \%$ & $22.7 \%$ \\
\hline \multirow[t]{2}{*}{ Bovine meat } & 10.8 & 10.7 & 10.3 & 9.7 & 9.6 \\
\hline & $29.0 \%$ & $25.8 \%$ & $22.2 \%$ & $18.1 \%$ & $16.0 \%$ \\
\hline \multirow[t]{2}{*}{ Mutton and goat meat } & 1.8 & 1.5 & 1.7 & 1.8 & 1.9 \\
\hline & $4.8 \%$ & $3.6 \%$ & $3.7 \%$ & $3.4 \%$ & $3.2 \%$ \\
\hline \multirow[t]{2}{*}{ Meat, other } & 0.8 & 0.8 & 0.7 & 0.8 & 0.9 \\
\hline & $2.1 \%$ & $1.9 \%$ & $1.5 \%$ & $1.5 \%$ & $1.5 \%$ \\
\hline \multirow[t]{2}{*}{ Capture } & 10 & 10.4 & 11 & 10.5 & 10 \\
\hline & $26.8 \%$ & $25.1 \%$ & $23.7 \%$ & $19.6 \%$ & $16.7 \%$ \\
\hline \multirow[t]{2}{*}{ Aquaculture } & 0.7 & 1 & 2.4 & 5.1 & 8.2 \\
\hline & $1.9 \%$ & $2.4 \%$ & $5.2 \%$ & $9.5 \%$ & $13.7 \%$ \\
\hline \multirow[t]{2}{*}{ Capture and Fisheries } & 10.7 & 11.4 & 13.4 & 15.6 & 18.2 \\
\hline & $28.7 \%$ & $27.5 \%$ & $28.8 \%$ & $29.1 \%$ & $30.3 \%$ \\
\hline Total & 37.3 & 41.5 & 46.5 & 53.7 & 60 \\
\hline
\end{tabular}

Source: FAOStat

Figures in percent are the respective contribution of each sector to the total figure 
Second, in term of efficiency, fish in aquaculture systems are very efficient converters of feed into protein - in fact far more efficient than most terrestrial livestock system (Fig. 6a). For instance, poultry converts about $18 \%$ of their consumed food and pigs about $13 \%$, as compared with $30 \%$ in the case of fish (Hasan and Halwart 2009). Production of $1 \mathrm{~kg}$ of beef protein requires $61.1 \mathrm{~kg}$ of grain, production of $1 \mathrm{~kg}$ of pork protein requires $38 \mathrm{~kg}$ of grain, while fish only requires $13.5 \mathrm{~kg}$ (Hall et al. 2011). Most of this difference comes from two biological characteristics of fish which give them great advantages over land-based livestock in growth performance: (i) the fact that fish are poikilotherms and therefore do not expend energy maintaining a constant body temperature; and (ii) the fact that, because finfish are physically supported by the aquatic medium, fewer resources are used on bony skeletal tissues, and a larger part of the food they eat is effectively allocated to body growth.

Third, in terms of carbon footprint, aquatic animal production systems have a lower carbon footprint per kilogram of output compared with other terrestrial animal production systems (Hall et al. 2011). As a consequence, nitrogen and phosphorous emissions ( $\mathrm{kg}$ of nitrogen and phosphorus produced per tonne of protein produced) from aquaculture systems are much lower than those in beef and pork production systems and slightly higher than that of poultry (Fig. 6b). In fact, some aquaculture production systems such as farming of bivalves absorb nitrogen and phosphorous emissions from other systems.

All these reasons are important arguments for giving fish far greater attention in the food security debate and in the current discussion about how to feed 9 billion by 2050. The CFS has started to recognize this and the report that was commissioned in 2012 indeed recommends that fish (a) becomes an integral element in inter-sectoral national FSN policies and programmes and (b) should be more systematically included in countries' nutritional programmes and interventions aiming at tackling micronutrient deficiencies especially among children and women (HLPE 2014: 18 Recommendation 1a and 1b).

\section{Conclusion}

Fish is already making a major contribution to human food supply and to the support of FSN for more than 660 million fish-workers and their families. It also provides more than 4.5 billion consumers with at least $15 \%$ of their average per capita intake of animal protein. In addition, because fish is more nutritious than staple foods such as cereals, providing in particular essential fatty acids and micronutrients, it can play an extremely important role in improving the nutritional status of individuals, in particular those at risk such as children and women.

Yet limited attention has been given so far to fish as a key element in FSN strategies at national level and in wider development discussions and interventions. Part of the problem might have been that specialists in fisheries debates have concentrated predominantly on questions of biological sustainability and on the economic efficiency of fisheries, neglecting issues linked to its contribution to reducing hunger and malnutrition and to supporting livelihoods (Kawarazuka and Béné 2010, 2011). On the other end of the spectrum, and with too few exceptions, most (non-fishery) food security experts and decision-makers seem unfamiliar with these facts and, therefore, unaware of the critical role that aquaculture is likely to play in the future. The problem is particularly pronounced in the current debate about how to make the food system more nutrition sensitive, i.e., how to change and improve the food

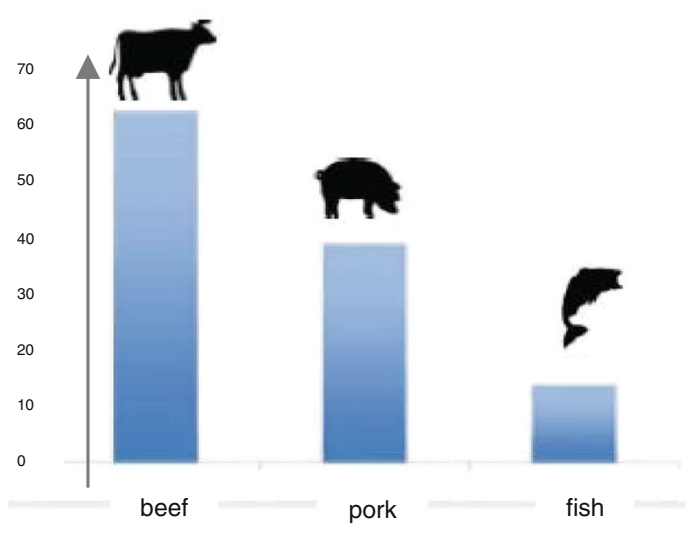

Conversion Efficiency

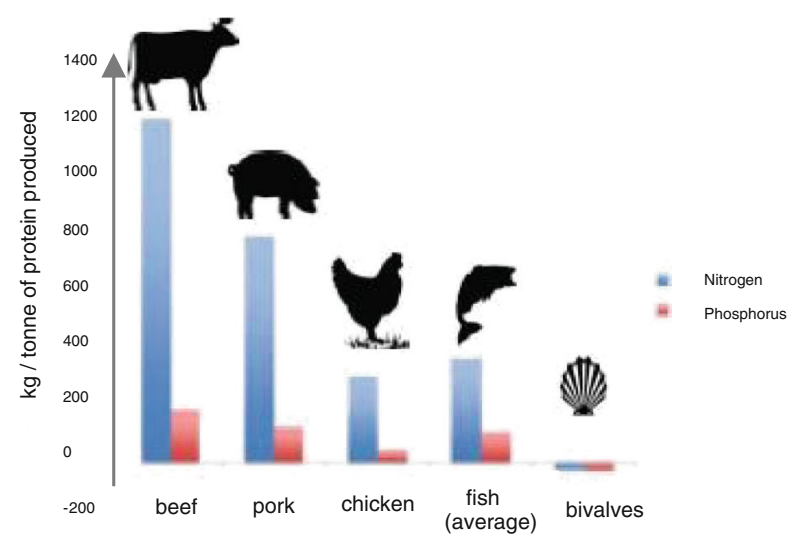

Emissions

Source: Data for fish are derived from Hall et al. (2011). Data for beef, pork and chicken are derived from Flachowsky (2002) in Poštrk (2003).

Fig. 6 a Feed and protein conversion efficiency of beef, pork and fish; b Nitrogen and phosphorous emissions for animal production systems. Source: Data for fish are derived from Hall et al. (2011). Data for beef, pork and chicken are derived from Flachowsky (2002) in Poštrk (2003) 
systems in order to advance nutrition. As a consequence, fish has so far been only marginally included in the international FSN debate. Many nutritional programmes are still not aware of, or not recognizing and building on the potential of fish for the reduction of micronutrient deficiency.

In this paper, we make the case that fish deserves more attention in food policies due to its importance in the food basket, its unique nutritional properties, its higher efficiency of production and carbon footprint compared to other forms of animal production systems. We acknowledge some challenges, however, especially in making fish more affordable for the poor or in maintaining - or restoring - the environmental sustainability of the sectors. We also stress that the ability to meet the potential average fish demands of 9 billion people masks inequalities and inequities in who eats the fish and who benefits from the value chains. At present, people in Africa, the poor in many societies, and women and minority groups, including small-scale fishing and aquaculture communities are in tension with large corporations and production units over access to fish and fish-related employment (HLPE 2014). We have shown that the best available projections for fish supply and demand are relatively positive in terms of the capacity to meet future demands, although more solid modelling is still needed to better incorporate demand projections. Climate change impacts on fish production also create uncertainty in the projections.

In conclusion, fish should certainly be on the menu.

Acknowledgments This paper was part of a workshop sponsored by the OECD Co-operative Research Programme on Biological Resource Management for Sustainable Agricultural Systems.

Open Access This article is distributed under the terms of the Creative Commons Attribution License which permits any use, distribution, and reproduction in any medium, provided the original author(s) and the source are credited.

\section{References}

Allison, E. H. (2011). Aquaculture, fisheries, poverty and food security. Working Paper 2011-65. Penang: WorldFish Center.

Allison, E. H., Béné, C., \& Andrew, N. L. (2011). Poverty reduction as a means to enhance resilience in small-scale fisheries. In R. S. Pomeroy \& N. L. Andrew (Eds.), Small-scale fisheries management - frameworks and approaches for the developing world (pp. 216238). Wallingford: CABI.

Allison, E. H., Delaporte, A., \& Hellebrandt de Silva, D. (2013). Integrating fisheries management and aquaculture development with food security and livelihoods for the poor. Report submitted to the Rockefeller Foundation. Norwich: School of International Development, University of East Anglia.

Arthur, R., Béné, C., Leschen, W., \& Little, D. (2013). Fisheries and aquaculture and their potential roles in development: an assessment of the current evidence. London, UK: Marine Resources Assessment Group Limited (MRAG). (http://r4d.dfid.gov.uk/pdf/outputs/ fisheries/61091-Fisheries_and_Aqua_Evidence_Review.pdf).
Barange, M., Merino, G., Blanchard, J. L., Scholtens, J., Harle, J., Allison, E. H., et al. (2014). Impacts of climate change on marine ecosystem production in fisheries-dependent societies. Nature Climate Change, 4, 211-216.

Béné, C. (2006). Small-scale fisheries: assessing their contribution to rural livelihoods in developing countries. FAO Fisheries Circular, No. 1008. Rome: Food and Agriculture Organization (FAO).

Béné, C., \& Friend, R. (2011). Poverty in small-scale inland fisheries: old issues, new analysis. Progress in Development Studies, 11(2), 119144.

Béné, C., Macfadyen, G., \& Allison, E. H. (2007). Increasing the contribution of small-scale fisheries to poverty alleviation and food security. FAO Fisheries Technical Paper, No. 481. Rome: FAO.

Béné, C., Steel, E., Kambala Luadia, B., \& Gordon, A. (2009). Fish as the "bank in the water" - evidence from chronic-poor communities in Congo. Food Policy, 34, 104-118.

Béné, C., Hersoug, B., \& Allison, E. H. (2010). "Not by rent alone": analysing the pro-poor functions of small-scale fisheries in developing countries. Development Policy Review, 28(3), 325-358.

Betru, S., \& Kawashima, H. (2009). Patterns and determinants of meat consumption in urban and rural Ethiopia. Livestock Research for Rural Development, 21(9/143).

Beveridge, M. C. M., Thilsted, S. H., Phillips, M. J., Metian, M., Troell, M., \& Hall, S. J. (2013). Meeting the food and nutrition needs of the poor: the role of fish and the opportunities and challenges emerging from the rise of aquaculture. Journal of Fish Biology, 83, 10671084.

Blanchard, J., Jennings, S., Holmes, R., Harle, J., Merino, G., Allen, I., et al. (2012). Potential consequences of climate change on primary production and fish production in 28 large marine ecosystems. Philosophical Transactions of the Royal Society, B: Biological Sciences, 367(1605), 2979-2989.

Bonham, M. P., Duffy, E. M., Robson, P. J., Wallace, J. M., Myers, G. J., Davidson, P. W., et al. (2009). Contribution of fish to intakes of micronutrients important for foetal development: a dietary survey of pregnant women in the Republic of Seychelles. Public Health Nutrition, 12(09), 1312-1320.

Boyd, C. E., Tucker, C., McNevin, A., Bostock, K., \& Clay, J. (2007). Indicators of resource use efficiency and environmental performance in fish and crustacean aquaculture. Reviews in Fisheries Science, 15, 327-360.

Caddy, J. F., \& Seijo, J. C. (2005). This is more difficult than we thought! The responsibility of scientists, managers and stakeholders to mitigate the unsustainability of marine fisheries. Philosophical Transactions of the Royal Society London B: Biological Sciences, 360(1453), 59-75.

Cheung, W. W. L., Lam, V., Sarmiento, J., Kearney, K., Watson, R., Zeller, D., \& Pauly, D. (2009). Large-scale redistribution of maximum fisheries catch potential in the global ocean under climate change. Global Change Biology, 16, 24-35.

Cheung, W. W. L., Dunne, J., \& Sarmiento, J. L. P. D. (2011). Integrating ecophysiology and plankton dynamics into projected maximum fisheries catch potential under climate change in the Northeast Atlantic. ICES Journal of Marine Science, 68, 1008-1018.

de Schutter, O. (2012). The right to food - Note to the General-Secretary from the Special Rapporteur on the right to food. New York: United Nation, Sixty-seventh session General Assembly.

Delgado, C. L., Crosson, P., \& Courbois, C. (1997). The impact of livestock and fisheries on food availability and demand in 2020. MSSD Discussion Paper, No.19. Washington, DC: IFPRI.

Eide, A., Bavinck, M., \& Raakjęr, J. (2011). Avoiding poverty: Distributing wealth in fisheries. In J. Svein \& A. Eide (Eds.), Poverty mosaics: Realities and prospects in small-scale fisheries (pp. 13-25). Dordrecht: Springer.

FAO. (2012). The state of world fisheries and aquaculture 2012. Rome: FAO. 
FAO. (2014). The state of world fisheries and aquaculture 2014. Rome: FAO.

FAO (nd). Post-harvest losses in artisanal fisheries. Focus fisheries and food security. Rome: FAO. http://www.fao.org/focus/e/fisheries/ proc.htm. Accessed Sept 2014.

Flachowsky, G. (2002). Efficiency of energy and nutrient use in the production of edible protein of animal origin. Journal of Applied Animal Research, 22(1), 1-24.

Garcia, S. M., \& Grainger, R. J. R. (2005). Gloom and doom? The future of marine capture fisheries. Philosophical Transactions of the Royal Society, B: Biological Sciences, 360, 21-46.

Garcia, S. M., \& Rosenberg, A. A. (2010). Food security and marine capture fisheries: characteristics, trends, drivers and future perspectives. Philosophical Transactions of the Royal Society, B: Biological Sciences, 365(1554), 2869-2880.

Grafton, R. Q., Hilborn, R., Squires, D., \& Williams, M. J. (2010). Marine conservation and fisheries management: At the crossroads pp. 3-19. In R. Q. Grafton, R. Hilborn, D. Squires, \& M. J. Williams (Eds.), Handbook of marine fisheries conservation and management. Oxford: Oxford University Press.

Hall, S. J., Delaporte, A., Phillips, M. J., Beveridge, M., \& O'Keefe, M. (2011). Blue frontiers: managing the environmental costs of aquaculture. Penang: The WorldFish Center.

Halpern, B. S., Walbridge, S., Selkoe, K., Kappel, C. V., Micheli, F., D'Agrosa, C., et al. (2008). A global map of human impact on marine ecosystems. Science, 319(5865), 948-952.

Hasan, M. R., \& Halwart, M. (Eds.). (2009). Fish as feed inputs for aquaculture; practices sustainability and implications. FAO Fisheries and Aquaculture Technical Paper. No. 518. Rome: FAO.

Heck, S., Béné, C., \& Reyes-Gaskin, R. (2007). Investing in African fisheries: building links to the millennium development goals. Fish and Fisheries, 8(3), 211-226.

High Level Panel of Experts. (2014). Sustainable fisheries and aquaculture for food security and nutrition. A report by the high level panel of experts on food security and nutrition of the committee on world food security. Rome: FAO

Hilborn, R. (2010). Apocalypse forestalled: why all the world's fisheries aren't collapsing. Science Chronicles, 5-9.

Hilborn, R. (2013). Environmental cost of conservation victories. Proceedings of the National Academy of Sciences, 110(23), 9187.

Kawarazuka, N., \& Béné, C. (2010). Linking small-scale fisheries and aquaculture to household nutritional security: a review of the literature. Food Security, 2(4), 343-357.

Kawarazuka, N., \& Béné, C. (2011). The potential role of small fish species in improving micronutrient deficiencies in developing countries: building evidence. Public Health Nutrition, 14(11), 1927-1938.

Kelleher, K. (2005). Discards in the world's marine fisheries - an update. FAO Fisheries Technical Paper. No. 470. Rome: FAO.

Larsen, R., Eilertsen, K., \& Elvevoll, E. O. (2011). Health benefits of marine foods and ingredients. Biotechnology Advances, 29, 508-518.

Lem, A., Bjorndal, T., \& Lappo, A. (2014). Economic analysis of supply and demand for food up to 2030 - Special focus on fish and fishery products. FAO Fisheries and Aquaculture Circular, No. 1089. FAO: Rome.

Merino, G., Barange, M., Mullon, C., \& Rodwell, L. (2010). Impacts of global environmental change and aquaculture expansion on marine ecosystems. Global Environmental Change, 20, 586-596.

Merino, G., Barange, M., Blanchard, J. L., Harle, J., Holmes, R., Allen, I., et al. (2012). Can marine fisheries and aquaculture meet fish demand from a growing human population in a changing climate? Global Environmental Change, 22, 795-806.

Miles, E. A., \& Calder, P. C. (2012). Influence of marine n-3 polyunsaturated fatty acids on immune function and a systematic review of their effects on clinical outcomes in rheumatoid arthritis. British Journal of Nutrition, 107(Supplement S2), S171-S184.
Myers, R. A., \& Worm, B. (2003). Rapid worldwide depletion of predatory fish communities. Nature, 423, 280-283.

Neiland, A.E., \& Béné, C. (2004). Poverty and small-scale fisheries in West Africa (eds.). Published by Kluwer Academic Publishers for the Food and Agriculture Organization, $254 \mathrm{p}$.

OECD-FAO (2013). Agricultural outlook 2013-2022. Paris: Organisation for Economic Co-operation and Development (OECD) and the Food and Agriculture Organization (FAO) of the United Nations.

Pauly, D. (2009). Aquacalypse now: the end of fish. The New Republic, 240, 24-27.

Pauly, D., Christensen, V., Dalsgaard, J., Froese, R., \& Torres, F. (1998) Fishing down marine food webs. Science, 279(5352), 860-863.

Pauly, D., Watson, R., \& Alder, J. (2005). Global trends in world fisheries: impacts on marine ecosystems and food security. Philosophical Transactions of the Royal Society, B: Biological Sciences, $360(1453), 5-12$.

Poštrk, V. (2003). The livestock revolution: dietary transition: global rise in consumption of animal food products. Environmental Science. Lund. Master: 50 pp. Lund, Sweden.

Prein, M., \& Ahmed, M. (2000). Integration of aquaculture into smallholder farming systems for improved food security and household nutrition. Food and Nutrition Bulletin, 21(4), 466-471.

Rangel-Huerta, O. D. R., Aguilera, C. M., Mesa, M. D., \& Gil, A. (2012). Omega-3 long-chain polyunsaturated fatty acids supplementation on inflammatory biomakers: a systematic review of randomised clinical trials. British Journal of Nutrition, 107(Supplement S2), S159-S170.

Rice, J. C., \& Garcia, S. M. (2011). Fisheries, food security, climate change, and biodiversity: characteristics of the sector and perspective on emerging issues. ICES Journal of Marine Science, 68(6), $1343-1353$.

Richardson, A. J., \& Montgomery, P. (2005). The Oxford-Durham study: a randomized, controlled trial of dietary supplementation with fatty acids in children with developmental coordination disorder. Pediatrics, 115(5), 1360-1366.

Roos, N., Islam, M. M., \& Thilsted, S. H. (2003). Small indigenous fish species in Bangladesh: contribution to vitamin $\mathrm{A}$, calcium and iron intakes. Journal of Nutrition, 133, 4021S-40126S.

Roos, N., Wahab, M. A., Chamnan, C., \& Thilsted, S. H. (2007). The role of fish in food-based strategies to combat Vitamin A and mineral deficiencies in developing countries. The Journal of Nutrition, 137(4), 1106-1109.

Shepherd, C. J., \& Jackson, A. J. (2013). Global fishmeal and fish-oil supply: inputs, outputs and markets. Journal of Fish Biology, 83(4), 1046-1066.

Smith, M. D., Roheim, C. A., Crowder, L. B., Halpern, B., Turnipseed, M., Anderson, J., et al. (2010). Sustainability and global seafood. Science, 327(5967), 784-786.

Speedy, A. W. (2003). Global production and consumption of animal source foods. The Journal of Nutrition, 133(11), 4048S-4053S.

Srinivasan, U. T., Cheung, W. W. L., Watson, R., \& Sumaila, U. R. (2010). Food security implications of global marine catch losses due to overfishing. Journal of Bioeconomics, 12(3), 183-200.

Steinacher, M., Joos, F., Frölicher, T. L., Bopp, L., Cadule, P., Cocco, V., et al. (2010). Projected 21 st century decrease in marine productivity: a multi-model analysis. Biogeosciences, 7, 979-1005.

Tacon, A. G. J., \& Metian, M. (2008). Global overview on the use of fish meal and fish oil in industrially compounded aquafeeds: trends and future prospects. Aquaculture, 285, 146-158.

Tacon, A. G. J., \& Metian, T. M. (2009). Fishing for feed or fishing for food: increasing global competition for small pelagic forage fish. AMBIO: A Journal of the Human Environment, 38(6), 294-30.

Tacon, A. G. J., Hasan, M. R., \& Metian, M. (2011). Demand and supply of feed ingredients for farmed fish and crustaceans: trends and prospects. FAO Fisheries and Aquaculture Technical Paper. No. 564. Rome: FAO. 
Thilsted, S. H. (2012). The potential of nutrient-rich small fish species in aquaculture to improve human nutrition and health. In R. P. Subasinghe, J. R. Arthur, D. M. Bartley, S. S. de Silva, M. Halwart, N. Hishamunda, et al. (Eds.) (2010), Farming the waters for people and food. Proceedings of the Global Conference on Aquaculture. Phuket, Thailand, (pp. 57-73). Rome: FAO and Bangkok: NACA.

Thilsted, S. H., Roos, N. \& Hassan, N. (1997). The role of small indigenous fish species in food and nutrition security in Bangladesh. WorldFish Centre Quarterly, 82-84.

Toufique, K. A., \& Belton, B. (2014). Is aquaculture pro-poor? Empirical evidence of impacts on fish consumption in Bangladesh. World Development, 64, 609-620.

Troell, M., Naylor, R. L., Metian, M., Beveridge, M., Tyedmers, P. H., Folke, C., et al. (2014). Does aquaculture add resilience to the global food system? Proceedings of the National Academy of Sciences, 111(37), 13257-13263

UNHRC (2012). The Rights to Fish for Food. New York, NY: United Nations Human Rights Commission. http://www.srfood.org/images/ stories/pdf/officialreports/20121030_fish_en.pdf/.

USDA (United State Department of Agriculture) (2011). National nutrient data base (http://ndb.nal.usda.gov/).

Williams, M. J. (2010). Gender dimensions in fisheries management. In R. Q. Grafton, R. Hilborn, D. Squires, M. Tait, \& M. Williams (Eds.), Handbook in marine fisheries conservation and management (pp. 72-86). Oxford: Oxford University Press.

World Bank. (2014). Fish to 2030 Prospects for Fisheries and Aquaculture. World Bank Report, No. 83177-GLB. Washington, DC: World Bank.

World Bank/FAO/WorldFish. (2012). Hidden harvest: The global contribution of capture fisheries. World Bank Report, No. 66469-GLB. Washington: World Bank.

Worm, B., Barbier, E. B., Beaumont, N., Duffy, E., Folke, C., Halpern, B. S., et al. (2006). Impacts of biodiversity loss on ocean ecosystem services. Science, 314(5800), 787-790. degree in Marine Environmental Sciences from the University of Marseille (France).

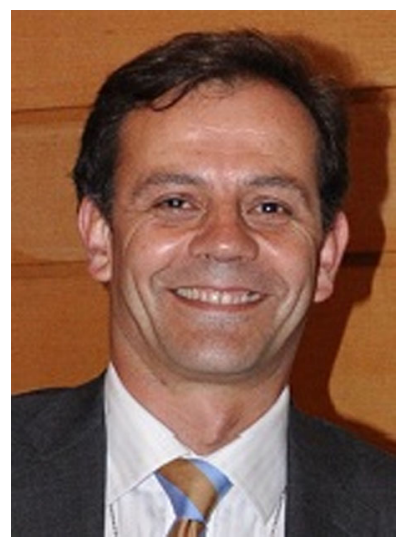

Manuel Barange is the Deputy Chief Executive and Director of Science at PML, and Honorary Professor at the University of Exeter, UK. His expertise includes climate and anthropogenic impacts on marine ecosystems, fish ecology, behaviour and trophodynamics, and fisheries assessment and management. He currently works on the impacts of climate change and economic globalization on marinebased commodities, and on the oceans' contributions to food security. He has published over 100 peer-review papers and in 2010 he was awarded the UNESCO-IOC Roger Revelle Medal for his contributions to marine sciences.

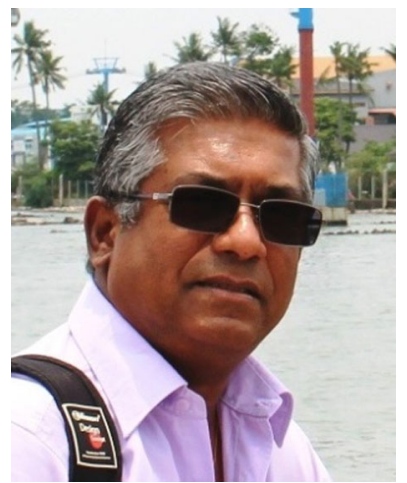

Rohana Subasinghe is currently the Chief of the Aquaculture Brach of FAO Fisheries and Aquaculture Department. He is a specialist in aquaculture development and aquatic animal health management. At FAO, he is also responsible for analyses of trends in aquaculture development globally and serves as the Technical Secretary to the Sub-Committee on Aquaculture of the Committee on Fisheries of the FAO. Since his graduation in 1980 from the University of Colombo, Sri Lanka, he has worked in all parts of the world, with most experience in Asia. Rohana earned his $\mathrm{PhD}$ from Stirling University, UK.

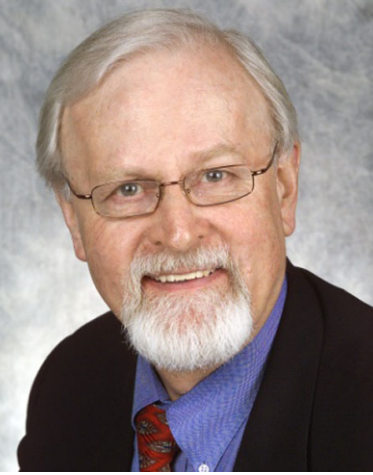

Per Pinstrup-Andersen is Professor Emeritus and Graduate School Professor at Cornell University, Adjunct Professor at Copenhagen University and Chair of the HLPE for Food Security. He is past Chairman of the Science Council of the CGIAR and Past President of the American Agricultural Economics Association (AAEA). He has a B.S. from Copenhagen University, an M.S. and Ph.D. from Oklahoma State University and honorary doctoral degrees from universities in the United States, the United Kingdom, Netherlands, Switzerland, and India. $\mathrm{He}$ is a fellow of the American Association for the Advancement of in Development Economics from the School of Development Studies at the University of East Anglia (UK), and a Masters 
Science (AAAS) and the American Agricultural Economics Association. $\mathrm{He}$ is the 2001 World Food Prize Laureate and the recipient of several awards for his research and communication of research results.

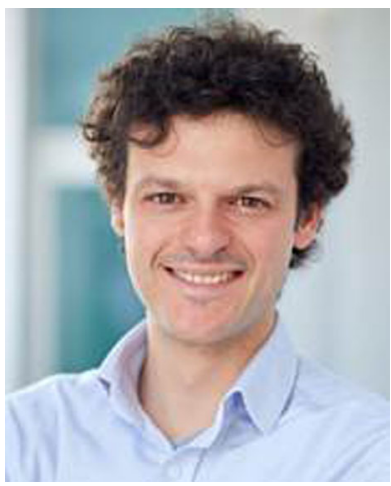

Gorka Merino's research focuses on the impact of environmental and socioeconomic factors on marine fisheries, including fishers' strategic decisions through game theoretic models, seeking to estimate the future availability of fish through future scenarios for fisheries and aquaculture and improving the scientific advice provided to Tuna Regional Management Organizations through Management Strategy Evaluation frameworks. His work has been carried out in the Instituto de Ciencias del

Mar (Spain, 2002-2007), the Plymouth Marine Laboratory (UK, 2008 2012) and AZTI (Spain, 2013-2014).

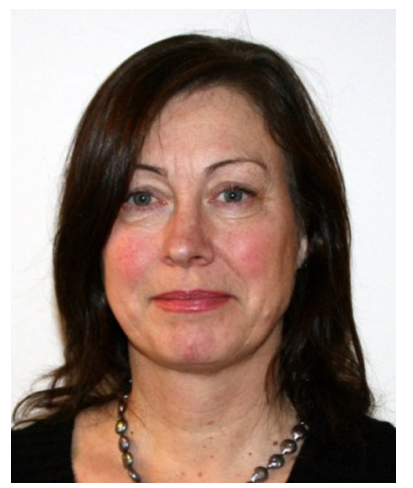

Gro-Ingunn Hemre is Director of Research at the Institute of Nutrition and Seafood Research (NIFES; Bergen, Norway). Her research focus has been on seafood and nutrition, and involves studies with activity throughout the food chain. Focus has been on nutrient availability and utilization. She is second in command in the steering committee for the Norwegian Scientific Committee for Food Safety, performing riskassessments.

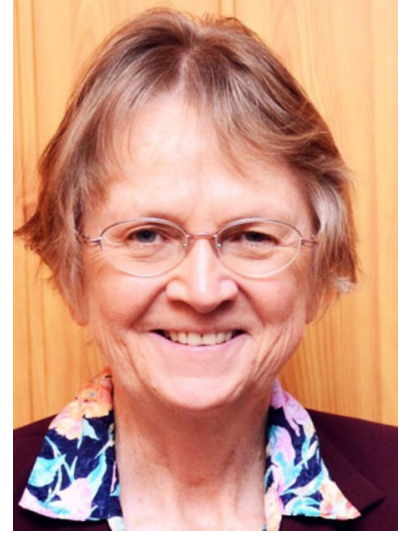

Meryl J. Williams has been active in research, research management and outreach in fisheries and aquaculture for food security, gender equality and social welfare, and aquatic environmental and resource conservation. She has worked for national (Australia), regional and international agencies and has been or is currently engaged in a number of nonexecutive leadership, review and editorial positions, including member of the Governing Board of the International Crop Research Institute for the Semi-Arid Tropics, and Vice-Chair of the Scientific Advisory Committee of the International Seafood Sustainability Foundation. She was elected a Fellow of the Australian Academy of Science, Technology and Engineering in 1993 and awarded an Australian Centenary Medal in 2003. In 2004, the Asian Fisheries Society elected her as an honorary Life Member. In 2010, she was named an 'Outstanding Alumnus' of James Cook University, Australia. 